\title{
Field Evaluation of Trichogramma chilonis (Ishii) for the Management of Shoot Borers in Sugarcane
}

\author{
M. Visalakshi*, B. Bhavani and S. Govinda Rao
}

Regional Agricultural Research Station, Anakapalle, Andhra Pradesh (531 001), India

\section{Article History}

Manuscript No. AR1435

Received in $19^{\text {th }}$ August, 2015

Received in revised form $8^{\text {th }}$ July, 2016

Accepted in final form $20^{\text {th }}$ July, 2016

\section{Correspondence to}

*E-mail: visalamahanthi@yahoo.co.in

\section{Keywords}

Field efficacy, Trichogramma chilonis, management, shoot borers, sugarcane

\begin{abstract}
Demonstrations were conducted to evaluate the efficacy of Trichogramma chilonis for the management of shoot borers in sugarcane in three villages of Visakhapatnam district, Andhra Pradesh during 2012-13. Field release of Trichogramma chilonis @ 50,000 ha $^{-1}$ release $^{-1}$ from 30 days after planting, four times at 7-10 day interval and two times after node formation reduced the early shoot borer by $89.67 \%$ and internode borer by $18.82 \%$ in biocontrol plots in comparison to farmers' plots. Adoption of integrated pest management practices viz., trash mulching@ $3 \mathrm{t} \mathrm{ha}^{-1}$ at planting and release of T. chilonis @ 50,000 ha-1 from 30 days after planting, four releases at 7-10 day interval and two releases after node formation effective in reducing early shoot borer by $78.31 \%$ and internode borer by $88.38 \%$ in IPM plots in comparison to farmers plots. The results showed that utilization of $T$. chilonis against shoot borers in biocontrol plot produced high cane yield of $92.82 \mathrm{t} \mathrm{ha}^{-1}$ with a benefit cost ratio of 2.21:1 compared to farmers plot (78.48 $\mathrm{t} \mathrm{ha}^{-1}$ with a B:C ratio of 1.82). Similarly, IPM plots recorded high cane yield i.e., $68.2 \mathrm{t} \mathrm{ha}^{-1}$ and higher $\mathrm{B}: \mathrm{C}$ ratio of 1.79 , compared to farmers plot (57.04 $\mathrm{t} \mathrm{ha}^{-1}$ with $\mathrm{B}: \mathrm{C}$ ratio of 1.15). Use of biocontrol agent in plant protection is a low cost technology with reduction in cost of plant protection to an extent of $79 \%$ in biocontrol plot and $41.2 \%$ in IPM plot with enhanced cane yields of $14.43 \mathrm{t} \mathrm{ha}^{-1}$ and $11.16 \mathrm{t} \mathrm{ha}^{-1}$ respectively.
\end{abstract}

\section{Introduction}

Sugarcane is an important cash crop in India which plays an important role in the economy of the country. Among several factors responsible for low yields, severe attack of insect pests at early and mature stages of the crop is the most significant one. Sugarcane borers are the most injurious pests among them all (Ashraf and Fatima, 1980). Sugarcane borer has become a challenging pest of sugarcane crop due to it's habit of feeding inside the plant parts where sprays are difficult to reach. Extensive and injudicious use of insecticides create health hazards, environmental pollution and resistance problem in insect pests (Mohyuddin et al., 1997; Soerjani, 1998). Further, indiscriminate use of pesticides kill the natural enemies resulting in flare up of pest population (Hamburg and Guest, 1997). In this context, biological control has now-a-days been emerged as most successful practice in management of major insect pests in several crops as well as in sugarcane. Many notable entomologists carried out several experiments on the potential activities of various natural enemies in bringing down the infestation of major insect pests in sugarcane plantation
(Sankaran 1974; David and Nandagopal, 1986). Inundative release of bio agents for the control of lepidopterous pests are being practiced in more than 32 million hectares each year around the world (Hassan, 1993). In sugarcane T. chilonis, a potential egg parasitoid, reduces stalk borer incidence by 55-60\% (Shenhmar et al., 2003). Utilization of T. chilonisin sugarcane produced most effective results in the management of borer complex. (Narasimha Rao et al., 2006) reported that $T$. chilonis@50,000 ha ${ }^{-1}$ release $^{-1}$ from 30 days after planting, four releases at 7-10 day interval results in less incidence of early shoot borer in sugarcane $(0.16 \%)$ compared to the untreated plots $(3.33 \%)$. Along with a new technology, Technology transfer is a key step for successful agriculture. On-farm testing has been identified as a tool to refine or modify the technology for successful adoption by the farming community.

Keeping in view, frontline demonstrations (FLDs) were conducted in farmer's fields at three villages covering an area of 30 ha to evaluate the efficacy of the egg parasitoid, T. chilonis against sugarcane shoot borers to reduce the plant protection costs in biocontrol plots and IPM plots in comparision with farmers practice. 


\section{Materials and Methods}

Frontline demonstrations were conducted in Chuchukonda, Munagapaka and Boyilakinthada villages of Visakhapatnam district, Andhra Pradesh during 2012-13 in farmer's fields with a view to evaluate the efficacy of the egg parasitoid, Trichogramma chilonis for the management of early shoot borer and internode borer in sugarcane. Large scale demonstrations were conducted on biocontrol method (release of T. chilonis against shoot borers) in comparison with farmer's practice of two insecticidal sprays in sugarcane under irrigated condition and on integrated pest management (IPM) adopting trash mulching and release of $T$. chilonis against shoot borers in comparison with farmer's practice of trash mulching in sugarcane under rainfed condition in these three villages covering an area of 30 ha undertaken by Regional Agricultural Research Station, Anakapalle. Field release of T. chilonis @ 50,000 ha $^{-1}$ release $^{-1}$ from 30 days after planting, four times at 7-10 day interval and two times after node formation was done in 8 ha block in each village and a separate block of 8 ha was maintained for farmers practice of plant protection with two insecticide sprays. No pesticides were used in the biocontrol plot. Similarly, IPM practice with trash mulching @ $3 \mathrm{t} \mathrm{ha}^{-1}$ at the time of planting and release of T. chilonis @ 50,000 ha ${ }^{-1}$ release $^{-1}$ from 30 days after planting, four times at 7-10 day interval and two times after node formation was demonstrated in 2 ha block in each village and a separate block of 2 ha was maintained with farmers practice of trash mulching. Standard agronomic practices were followed as per the requirement of the crop. After the appearance of moths, the weekly releases of T. chilonis were made in demonstration plots with trichocards having 20,000 parasitoid eggs near to emerge installed on lower side of leaves opposite to the direction of sun. These trichocards were prepared by pasting parasitoid eggs on yellow paper cards. Data on cumulative incidence of early shoot borer as \% deadhearts (DH) from 45 days to 120 days after planting was recorded from 50 randomly selected canes from each plot at the time of harvest. Data on cane yield, cost on plant protection and benefit cost ratio were also recorded in all the three villages in demonstration plots as well as farmer's practice plots and was analyzed using paired $t$ test.

\section{Results and Discussion}

Results of sugarcane early shoot borer and internode borer damage in bio-control fields where egg parasitoids, Trichogramma chilonis were released and its comparison with farmer's practice at three locations in irrigated sugarcane were presented in Table 1.

Early shoot borer damage in biocontrol fields was in the range of 1.89 to $2.68 \% \mathrm{DH}$ with a mean damage of $2.38 \% \mathrm{DH}$. On the other hand, in farmer's fields, it ranged from $20.46-26.2 \% \mathrm{DH}$ with a mean damage of $23.04 \% \mathrm{DH}$. Internode borer damage in biocontrol fields was in the range from 4.3 to $5.81 \% \mathrm{DH}$ with a mean damage of $5.22 \% \mathrm{DH}$. Internode borer damage in farmer's fields ranged between $5.8-7.41 \%$ DH with a mean damage of $6.43 \% \mathrm{DH}$. Reduction in early shoot borer damage biocontrol fields was ranged from 87.49 to $91.58 \%$ DH with a mean of $89.67 \% \mathrm{DH}$. Reduction in internode borer damage biocontrol fields ranged from 8.4 to $25.86 \%$ with a mean of $18.82 \% \mathrm{DH}$. Results of three locations showed the effectiveness of $T$. chilonis in suppressing the early shoot borer

Table1: Efficacy of utilization of Trichogramma chilonis in the management of shoot borers in sugarcane under irrigated conditions sugarcane

\begin{tabular}{llccccccccc}
\hline Location & Treatments & $\begin{array}{c}\text { Incidence } \\
\text { of ESB } \\
\text { (\% DH) }\end{array}$ & $\begin{array}{c}\text { \% Re- } \\
\text { duction } \\
\text { in ESB }\end{array}$ & $\begin{array}{c}\text { Inci- } \\
\text { dence of } \\
\text { INB }(\%)\end{array}$ & $\begin{array}{c}\text { \% Re- } \\
\text { duction } \\
\text { in INB }\end{array}$ & $\begin{array}{c}\text { Cane } \\
\text { yield } \\
\left(\mathrm{t} \mathrm{ha}^{-1}\right)\end{array}$ & $\begin{array}{c}\text { \% In- } \\
\text { crease } \\
\text { in yield }\end{array}$ & $\begin{array}{c}\text { Cost of } \\
\text { PP (₹ } \\
\left.\text { ha }^{-1}\right)\end{array}$ & $\begin{array}{c}\text { Net } \\
\text { return } \\
\left(₹ \text { ha }^{-1}\right)\end{array}$ & $\begin{array}{c}\text { Benefit: } \\
\text { cost ra- } \\
\text { tio }\end{array}$ \\
\hline Chuchukonda \\
village & Biocontrol plot & 2.68 & 89.77 & 5.81 & 21.59 & 96.89 & 14.8 & 525 & 98,877 & 2.31 \\
Munagapaka & Farmer's plot & 26.2 & & 7.41 & & 84.4 & & 3,000 & 73,920 & 1.95 \\
village & Biocontrol plot & 2.56 & 87.49 & 5.56 & 8.40 & 88.96 & 25.58 & 525 & 84,603 & 2.12 \\
Boyilakinthada & Farmer's plot & 20.46 & & 6.07 & & 70.84 & & 1500 & 51,012 & 1.67 \\
village & Biocontrol plot & 1.89 & 91.58 & 4.3 & 25.86 & 92.6 & 15.46 & 525 & 91,155 & 2.21 \\
Mean & Farmer's plot & 22.45 & & 5.8 & & 80.2 & & 3000 & 66,360 & 1.85 \\
& Biocontrol plot & 2.38 & 89.67 & 5.22 & 18.82 & 92.82 & 18.61 & 525 & 91,551 & 2.21 \\
t- cal & Farmer's plot & 23.04 & & 6.43 & & 78.48 & & 2,500 & 63,764 & 1.82 \\
\hline
\end{tabular}

ESB : Early shoot borer ; INB: Internode borer ; PP : Plant protection ; DH: Deadheart; Biocontrol plot: Trichogramma chilonis@ 90,000 ha $^{-1}$ release ${ }^{-1}$ from 30 days after planting, four times at 7-10 day interval and two times after node formation. Farmer's plot: Two insecticide sprays. 
and inter node borer in biocontrol fields.

Effectiveness of trash mulching and release of egg parasitoids, Trichogramma chilonis, as a IPM demonstration for the management of sugarcane shoot borers and its comparision with farmers practice in rainfed sugarcane was presented in Table 2.
Early shoot borer damage in IPM plot and farmer's fields was $4.28 \% \mathrm{DH}$ and $19.73 \%$ respectively. While, internode borer damage was recorded as $1.59 \%$ and $13.68 \%$ respectively in the above two plots. Adoption of IPM practices resulted in reduction of early shoot borer damage by $78.31 \%$ and internode borer damage by $88.38 \%$. Comparison of the above results

Table 2: Effectiveness of trash mulching and release of Trichogramma chilonis against shoot borers in rainfed sugarcane

\begin{tabular}{lccccccccc}
\hline Treatments & $\begin{array}{c}\text { Incidence } \\
\text { of ESB } \\
\text { (\% DH) }\end{array}$ & $\begin{array}{c}\text { \% Reduc- } \\
\text { tion in } \\
\text { ESB }\end{array}$ & $\begin{array}{c}\text { Incidence } \\
\text { of INB } \\
(\%)\end{array}$ & $\begin{array}{c}\text { \% Reduc- } \\
\text { tion in } \\
\text { INB }\end{array}$ & $\begin{array}{c}\text { Cane } \\
\text { yield } \\
\left(\mathrm{t} \mathrm{ha}^{-1}\right)\end{array}$ & $\begin{array}{c}\text { Percent } \\
\text { Inrease in } \\
\text { yield }\end{array}$ & $\begin{array}{c}\text { Cost of } \\
\text { PP } \\
\left(₹ \mathrm{ha}^{-1}\right)\end{array}$ & $\begin{array}{c}\text { Net } \\
\text { return } \\
\left(₹ \mathrm{ha}^{-1}\right)\end{array}$ & $\begin{array}{c}\text { Benefit: } \\
\text { cost ratio }\end{array}$ \\
\hline $\begin{array}{l}\text { IPM block } \\
\text { Farmer's } \\
\text { practice block }\end{array}$ & 4.28 & 78.31 & 1.59 & 88.38 & 68.2 & 19.51 & 1,275 & 60,125 & 1.79 \\
t- cal & 19.73 & & 13.68 & & 57.04 & & 750 & 49,225 & 1.15 \\
\hline
\end{tabular}

ESB : Early shoot borer ; INB: Internode borer ; PP : Plant protection ; DH: Deadheart ; IPM block : Trash mulching and Trichogramma chilonis @ 50,000 ha ${ }^{-1}$ release $\mathrm{e}^{-1}$ from 30 days after planting, four times at 7-10 day interval and two times after node formation. Farmer's practice block : Trash mulching

showed the effectiveness of $T$. chilonis towards suppression of early shoot borer and internode borer damage in biocontrol fields and IPM fields. These findings are in line with the results reported earlier by (Ashraf et al., 1993), that borer damage on internode basis at the time of harvest was in the range of 4 to $35.5 \%$ with an average of $14.1 \%$. Similar results were reported by (Rana et al., 2007) showing 11.33 and 12.65 $\%$ borer damage to canes in 2002 and 2003, respectively in check plots and with 6.75 and $6.4 \%$ damage in T. chilonis released fields. Studies conducted by (Narasimha Rao et al., 2006) showed that T. chilonis @ 50,000 ha ${ }^{-1}$ release $^{-1}$ from 30 days after planting, four releases at $7-10$ day interval resulted in less incidence of early shoot borer in sugarcane $(0.16 \%)$ compared to the untreated plots (3.33\%). Trash mulching was proved to be effective in minimizing infestation level of early shoot borer than chemical control (Raja et al., 1991). It was observed that trash mulch has influenced the micro climate of the sugarcane crop by way of conserving soil moisture and reduced the early shoot borer incidence and the findings are in agreement with Singh (1983) and (Kathiresan et al., 1991). (Makhdum et al., 2001) reported that infestation of the borer was lower in the mulched plots due to lower larval survival and a higher prevalence of various natural enemies.

Biocontrol fields recorded significantly higher cane yield $\left(92.82 \mathrm{t} \mathrm{ha}^{-1}\right)$ in comparision with farmer's fields (78.48 t $\mathrm{ha}^{-1}$ ) with an additional yield of $14.34 \mathrm{t} \mathrm{ha}^{-1}$ over farmer's fields which is significantly superior. The benefit cost ratio calculated for the demonstration as well as farmer's practice plots was also found to be significantly higher with B:C ratios of 2.21 and 1.82 respectively. Highest net return was recorded in biocontrol fields released with T. chilonis (₹ 91,551 ha-1) compared to farmer's fields ( $₹ 63,764 \mathrm{ha}^{-1}$ ). Thus, by adopting biological control practices for the management of sugarcane shoot borers, farmer's could earn an additional income of ₹ 25,812 ha $^{-1}$ over farmer's practice of chemical plant protection measures.

Similar observations were recorded with IPM fields, resulting in higher cane yield $\left(68.2 \mathrm{tha}^{-1}\right)$ in comparision with farmer's fields $\left(57.04 \mathrm{t} \mathrm{ha}^{-1}\right)$ with an additional yield of $11.16 \mathrm{t} \mathrm{ha}^{-1}$, leading to superior B:C ratio of 1.79 over farmers' practice of 1.15. Highest net return was recorded in IPM fields ( $₹ 60,125$ $\mathrm{ha}^{-1}$ ) compared to farmer's fields ( $₹ 49,225 \mathrm{ha}^{-1}$ ). Adoption of IPM practices for the management of sugarcane shoot borers resulted in an additional income of ₹ 10,900 ha- over farmer's practice of plant protection.

Adoption of biological measures over the farmers' traditional plant protection measures lead to increased income to the farmers' owing to the higher cane yields and low cost on plant protection measures in both the demonstrations. Thus, these front line demonstrations conducted at farmer's fields clearly established the advantage of the egg parasitoid, T. chilonis release in sugarcane over farmer's practice of plant protection.

\section{Conclusion}

Utilization of Trichogramma chilonis in sugarcane significantly reduced early shoot borer and internode borer in biocontrol plots as well as in the IPM plots along with trash mulching compared to farmer's practices with increased cane yields and higher cost benefit ratio. Use of $T$. chilonis for plant protection is a cost effective technology as it has reduced the 
plant protection costs to the tune of ₹ $1975 \mathrm{ha}^{-1}$ compared to the farmers' practices.

\section{Acknowledgement}

The autor is thankful to the department of agriculture, Andhra Pradesh for the financial assistance through ATMA programme for conducting demonstrations in farmer's fields.

\section{References}

Ashraf, Fatima, M.B., Ali, S.S., 1995. Significance of Trichogramma chilonis (Ishii) in controlling the sugarcane borers. In: Proceedings of pakistan congress zoology 15, 171-176.

David, H., Nandagopal, V., 1986. Pests of sugarcanedistribution symptomatology of attack and identification. In: David, H., Eswaramoorthy, S., Jayanthi, R. (Eds.), Sugarcane Entomology in India. Sugarcane Breeding Institute, Coimbatore, 1-19.

Hamburg, H.V., Guest, P.J., 1997. The impact of insecticides on beneficial arthropods in cotton agroecosystem in South Africa Archives environmental Contamination Toxicology 8(8), 786.

Hassan, S.A., 1993. The mass rearing and utilization of Trichogramma chilonis to control lepidopterous pests. Achievements and outlook. Pesticide Science 37, 387-91.

Kathiresan, G., Manoharan, M., Veerabhadram, V., 1991. Effect of trash much as cultural measure to control weed growth and shoot borer in sugarcane crop. Co-operative Sugar 22, 799-801.

Makhdum, A.H., Cock, M.J.W., Shehzad, A., 2001. Effect of trash mulching on the infestation of stem borer, Chilo infuscatellus Snellen, its natural enemies and on over all sugar productivity in the Habib Sugar Mills area at Nawabshah, Sindh. Pakistan Sugar Journal 16, 3, 6-14.

Mohyuddin, A.L., Jilani, G., Khan, A.G., Hamza , A., Ahmed, A. Mohamood., 1997. Integrated pest management of major cotton pests by conservation, redistribution and augumentation of natural enemies. Pakistan Journal of Zoology 29(3), 293-298.

Narasimha Rao, Ch. Venugopala Rao, V., Bhavani, B., 2006. Efficacy of Trichogramma chilonis against early shoot borer, Chilo infuscatellus Snellen under sugar factory operational areas of Coastal Andhra Pradesh. Journal of Biological Control 20(2), 225-228.

Narasimha Rao, Ch. V., Venugopala Rao, N., Bhavani, B., 2008. Field efficacy of integrated management practices against insect pest complex in sugarcane. Pestology 32(11), 19-21.

Raja, J., John Ambrose, H., Rajasekharan, 1991. Control of shoot borer Chilo infuscatellus Snellen of sugarcane through agronomic practices. In: Proceedings of $53^{\text {rd }}$ Annual Convention of Deccan Sugarcane Research Technologists Association I, 53-55.

Rana, Z.A., Haq, I., Malik, N.A., Akhar, A.S., 2007. Effects of trash mulching and Trichogramma chilonis (Ishii) on sugarcane borers infestation. Journal of Agricultural Research 45, 161-164.

Sankaran, T., 1974. Natural enemies introduced in recent years for biological control of sugarcane pests in India. Indian Journal of Agricultural Science 44, 425-433.

Shenhmar, M., J. Singh, S.P., Singh, K.S., Brar, D., Singh, P.L., Tandon., Ballal, C.R., Jalali, S.K., Rabindra, R.J., 2003. Effectiveness of Trichogramma chilonis Ishii for the management of Chilo auricillus Dudgeon on sugarcane in different sugar mill areas of the Punjab. Biological control lepidopterous pests. In: Proceedings of Symposium on Biological Control of Lepidopteran pests, July 17-18, 2002 Bangalore, India, 333-335.

Singh, H.N., 1983. Seventy years of sugarcane research (1912-1981). Publication of U.P Council of Sugarcane Research, Shahjahanpur, 36-44.

Soerjani, M., 1998. Current trend in pesticide usage in some Asian countries. Environmental Implications of Research. Pesticides International Atomic Energy Agency, Vianna Austria, 219-234. 